\title{
Visual Identity of Riga 21st Century Multi-Apartment Developments
}

\author{
Santa Freimane* \\ Riga Technical University, Riga, Latvia
}

Received 2020-09-10; accepted 2021-04-23

\section{Keywords}

Contemporary architecture, Riga, urban housing, visual identity.

\begin{abstract}
It is claimed that rapid changes, including globalization and urbanization, may lead to uniform urban environment. Therefore, it is crucial to address issues in terms of local architecture. This research particularly focuses on the visual identity of Riga 21st century residential developments. Theoretical studies and empirical research methods were used. According to the research results, the most typical characteristics are linear building blocks, symmetric arraignment of façade elements, polychrome façade colour approach and usage of white/grey/ black colour palette. However, considering variety of visual expressions as well as different architectural and spatial situations, there cannot be determined one exact visual identity.
\end{abstract}

\section{Introduction}

Urban environment is changing over time, including under influence of new construction. It is widely claimed that in times of globalization and urbanization, architecture starts to lose its local character and identity. In Riga, during the past two decades more than 24 thousand new apartments have been constructed [1]-[3]. However, it is not clear, how these developments contribute to visual quality and overall expression of urban environment identity. This

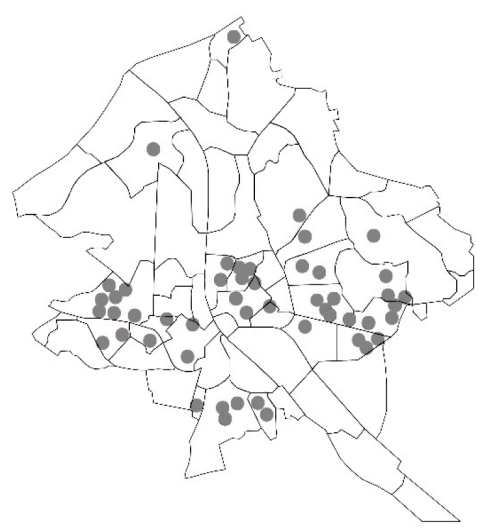

Fig. 1. 50 largest apartment complexes built in Riga from 2000-2019 [4]-[6]. paper defines the following research questions: What is the concept of identity in built environment? What is the context of residential environment development? What are the main trends and approaches regarding visual identity of the $21^{\text {st }}$ century new residential developments in Riga?

The main research object are developments which were built during 2000-2019. For more detailed research, 50 largest residential projects with at least 2 buildings and completed first construction phase were selected. Review of relevant scientific literature was used to ground the theoretical framework. The analysis of legislation, urban plans and other documented sources was used to explore the Riga city context. Field studies were used to collect and analyse empirical data. Comparative analysis method was used to identify common visual characteristics of Riga contemporary housing developments.

\section{Identity of Built Environment}

\section{A. Place Identity, Sense of Place and Urban Branding}

According to K. Lynch, identity can be defined as 'the extent to which a person can recognize or recall a place as being distinct from other places' [cited in 7]. Environmental and social psychologists Harold M. Proshansky, Abbe 
K. Fabian, and Robert Kaminoff, stated that one of a person's self-sub-structures is a place identity, which is based on experiences and feelings of physical environment [8]. As stated by Montgomery, place is a middle point of relationships between activities, form and image. Form depends of such factors as scale, intensity, space to building ratios, etc. Image consists of attributes like symbolism, receptivity, psychological access and others. In turn, activities include vitality, street life, events, flow, etc. [9]. Sense of place has been widely discussed and investigated across many disciplines, including human geography, psychology and others. As stated by Tuan, the sense of place is 'the meanings and attachment to a setting held by an individual or group' [cited in 10]. For effective sense of place, it is necessary to achieve diversity and place identity, thus forming imageability, visual enclosure and other perceptual qualities. In contrary, homogeneity can lead to weak sense of place. However, also less pleasing architecture in some cases may have high artistic value by local inhabitants due to the impact of culture, social interactions, meanings and other aspects [11]. Urban branding is a new concept which is implemented to achieve certain sustainability goals and promote the city's image. To achieve effective image, there are used two types of elements. Firstly, those which create every urban structure, such as described in K. Lynch's theory: paths, edges, districts, nodes, and landmarks, and secondly, unique characteristics, such as colours, skyline, cultural activity, etc. which are specific to the particular place. Urban branding can help to elevate city image, achieve competitive advantages and strengthen economic performance [12].

\section{B. Physical Features}

Although theories of place identity, sense of place and urban branding emphasize the role of culture, psychology and other dimensions, they all take place in a built environment. Human brain records and proceeds visual inputs of surroundings, which in real time gives outputs, so people can act accordingly [13]. Therefore, architecture and its physical features play a significant role. These features shape architectonic perspective, connect exterior with interior and provide continuity of development in existing urban structure [14]. One of the main physical features of architecture is a form. As stated in E. N. Bacon's book "The Design of Cities": "Architectural form is the point of contact between mass and space.... Architectural forms, textures, materials, modulation of light and shade, colour, all combine to inject a quality or spirit that articulates space. The quality of the architecture will be determined by the skill of the designer in using and relating these elements, both in the interior spaces and in the spaces around buildings" [cited in 15]. In 1896, in his essay "The Tall office Building Artistically Considered" architect Louis H. Sullivan introduced the phrase "form follows function". According to Sullivan, everything in nature has a form which helps to distinguish that from others. Moreover, the form of a building not only attracts the eye to the exterior and creates the first impression but also may generate an idea of the building function [16].

Character of buildings in the last centuries has been influenced by several ideas and developed variety of discourses. The Adolf Loos essay "Ornament and Crime”, the Ludwig Mies van der Rohe's phrase "Less is more" or Robert Venturi's phrase "Less is a bore" - all can be interpreted in terms of architectural identity. In creation of architecture, the mass and spaces are arranged into composition. During the design phase, different elements obtain their own place in accordance with the main concept and approach of the overall composition. This order generates the character and appearance of the final design. To achieve a certain character of the building, specific compositional principles are used in design, such as symmetry, contrast, hierarchy, rhythm and others. For example, symmetry creates the feeling of security, safety and solidity. In turn, contrast creates variety and visual interest [17].

At the beginning of the 20th century, colour usage in built environment has been influenced by Le Corbusier, B. Taut, Rietweld, L. Barragan and others. In 1924, in Utrecht Schröder House designed by Rietweld was completed. It was the first architectural manifesto by the De Stijl group. Each plane was classified by different colour. For surfaces the shades of grey, white and black were used, but for linear elements - red, blue and yellow [18]. This example emphasizes that also colour can be used as an architectural expression attribute. It may create different characteristics, such as harmony, unity or contrast. Moreover, it can affect people's perception, psychological mood and response to their surroundings [19]. Similarly, the director of Haus der Farbe, Steffanie Wettstein, states that "Colour can be used strategically to orchestrate spatial sequences or to visualise tectonics; it can support light and shadow, make surfaces an optical and haptic experience and much more. Colour is one of the oldest architectural design elements - colourless architecture does not exist." [20].

\section{The Riga Context}

\section{A. Historical Evolution}

Identity of built environment is a phenomenon created by contextual conditions. In this regard, historical evolution is one of the main aspects. Since the 13 th century, a great architectural heritage of Riga has been built, which nowadays is included in UNESCO world heritage list. One of the most famous medieval period architectural masterpieces is residential building ensemble Trīs brālli (Three Brothers). Two of these buildings reflect 
medieval layout characteristics, where large entrance halls are located on the ground floor, living rooms on the yard side and storages on upper floors. However, these buildings partially have been modified in the 19th century (Table I a). Baroque style at best can be characterised with richly decorated mansard roofs of rich citizens (Table I b). In the Classicism period, great attention was paid to the clarity of forms and rational expression, modelled on the classically 'pure' architecture of ancient Greece. Timber residential buildings of the Classicism period mostly had a side extension for entrance function, but in the mezzanine were located 3 or 5 windows (Table I c) [21]. As in many other European cities, medieval fortifications were destroyed in the middle of the 19th century and replaced with a unique belt of boulevards [21], [22]. In the second half of the 19th century, during the Eclecticism period, for the artistic decoration of buildings was used as formal means of expression of all styles previously known in history, choosing them according to the building's meaning, location or other circumstances (Table I d). At the beginning of the 20th century Art Nouveau took the lead. The facades of Art Nouveau buildings are decorated with relieflines, circles and plant stylizations incorporated into the architectural design of the building's basic form. Moreover, the complex window layout matches the convenient interior design and overall planning [21] (Table I e). Art Deco was a reflection of Art Nouveau style in the twenties of the 20 th century. It is characterized by the use of ornaments inscribed in semicircles or other geometric figures, edged and exalted, but relatively restrained in the decoration of building facades or interiors (Table I f). Modern Movement or Functionalism was the main style in the thirties of the 20th century. It completely abandoned ornamental decorations, thus creating the art of 'clean' planes and volumes. Buildings of this style are distinguished by a strongly articulated, cubic structure of building structures, flat roofs, horizontal window strips and wide glazing (Table I g) [22]. After World War II, it was necessary to manage the damage of the war, including the restoration of housing stock. New political situation and ideology, and prefabrication of construction elements, led to massive standard construction of large-scale housing estates [21], [22] (Table I h). After independence, in 1991, spatial planning of the country experienced a transition to a free-market economy, privatization, and

TABLE I

Evolution of Riga Residential Architecture (Photo: Author, Description [21])

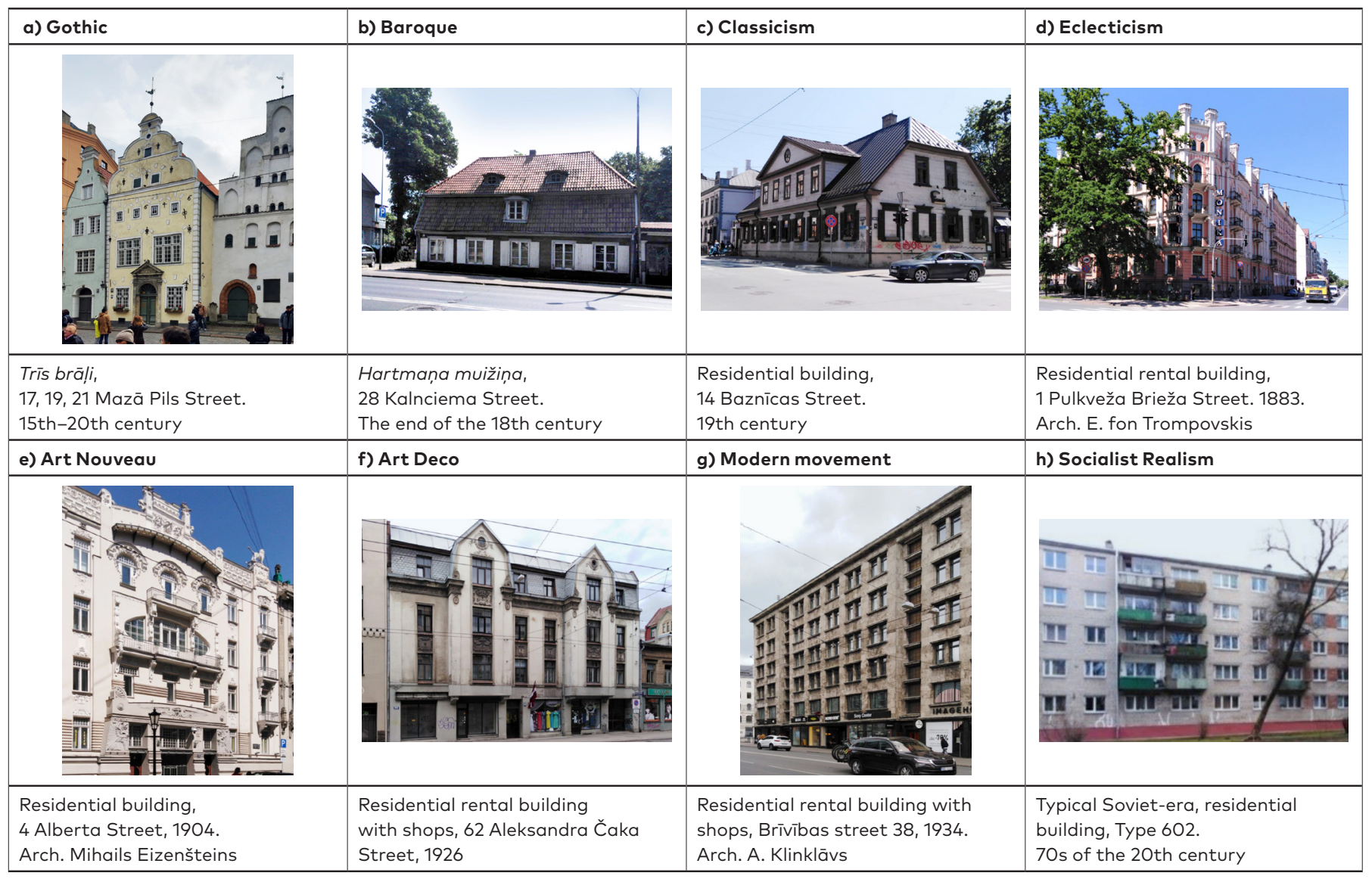


the democratization of social and cultural life [21]. The most appropriate examples in Table I, as well as in further tables, are chosen to represent each particular style/ characteristic.

Riga historical residential environment is not only in many cases valuable architectural heritage but also sets the context for further urban developments. The analysis of historical evolution defines three main settings. Firstly, Riga historical centre and its protection zone with rich historical heritage since the 13th century. Secondly, residential neighbourhoods of Soviet era with standard large-scale housing estates. Thirdly, new development areas without direct impact of historical constructions.

\section{B. Identity Determination}

Search for identity is a global issue. At the moment Riga faces a lot of challenges, including weak regulatory framework, ineffective cooperation, poorly developed rental market, urban sprawl and others. One of the Sustainable Development Strategy goals is to ensure "quality living environment and accessible housing" [24]. To achieve this goal, it is planned to renovate existing residential buildings, promoting new construction of different housing forms, thus creating offers for wide range of households, developing appropriate rental market, expanding support regarding housing issues, enlarging social housing stock, etc. [23]. Moreover, According to Sustainable Development Strategy, in 2030 Riga should be an internationally recognized metropolis of Northern Europe [24]. Identity of urban environment is one of the issues arising in this context and global tendencies. As stated by Rem Koolhaas, a national identity has been sacrificed to modernity [25]. However, according to the Davos Declaration the central role in the built environment has to be paid to culture: "Culture enables and drives economic, social and environmental sustainability. It shapes our identities and defines our legacies. Therefore, culture must be placed at the centre of development policies, and its contribution to the pursuit of the common good must be emphasised. There can be no democratic, peaceful and sustainable development if culture is not at its heart." The Davos Declaration also stresses the need for a high-quality Baukultur, which improves the sense of place, fosters an inclusive society and promotes integration and civic awareness [26].

Latvian architecture is an integral part of national identity. Architecture forms the spatial identity of the region and affirms special qualities in the local context [27]. Although identity in any field is difficult to define precisely, the Nordic sense, as well as influence of Nordic architecture in Latvia can be traced since the beginning of the 20th century as well as the direction of national romanticism. The Nordic mentality, including the related language of form and social ideas, were binding Latvian architects in the wave of post-war modernism in the 20 th century. Even now, a Nordic sense of belonging is associated with the future of Latvian architecture [27]. As stated by Artis Zvirgzdiňš, an editor of the A4D architectural platform, identity consists of two main aspects. The first one is what we strive for, in other words, an image what we want to achieve. The second aspect is what we are in reality, including our existing spatial environment and everything what is already built. A. Zvirgzdinš points out that it is not worth looking for identity in national forms and clichés, but it has to be found in a deeper meaning of Architecture its functionality, respect of the place and context and added value to society [28]. As mentioned by architect Brigita Bula, Latvian architecture at the moment does not have a stabilized identity, but there is a tendency to look forward to it. However, the search for identity abroad has resulted in repetition of foreign architecture without the context. B. Bula states that modern identity should be found by looking around, evaluating the context of the place and interpreting them in a new way with materials and possibilities of nowadays [29].

\section{Visual Identity Assessment}

Identity of urban environment is a complex concept and includes a variety of aspects. Some of them such as materiality needs in-depth data about project design and construction. This research is based on field studies, and assessment of visual identity is limited to three attributes which jointly frame the individual characteristic of a building. These attributes are: overall building form, composition of facade elements, and colour approach/palette of facades. This is the first step towards investigation of architectural identity in Latvian contemporary housing architecture. Further studies could explore material usage, including the impact of texture, light and other factors.

\section{A. Building Form}

Building form depends on a wide range of factors such as plot configuration, building regulations, and others. However, the form has a huge impact - it can create interest and sense of belonging, or contrary a monotonous look, difficulties to orient, etc. [13]. The study findings show that mostly linear blocks are used, which in most cases reflects the surrounding building and blends in the context. However, in $28 \%$ of cases tower blocks are used. These cases mostly are height accents of neighbourhood. Remaining projects used shaped, curved blocks, or mixed strategies. In general, it can be concluded that various strategies have been implemented, thus creating overall diverse urban environment expressions (Table II). 
TABLE II

Building Forms of Riga Contemporary Urban Housing (Photo, Description: Author, Maps: adapted from [4])

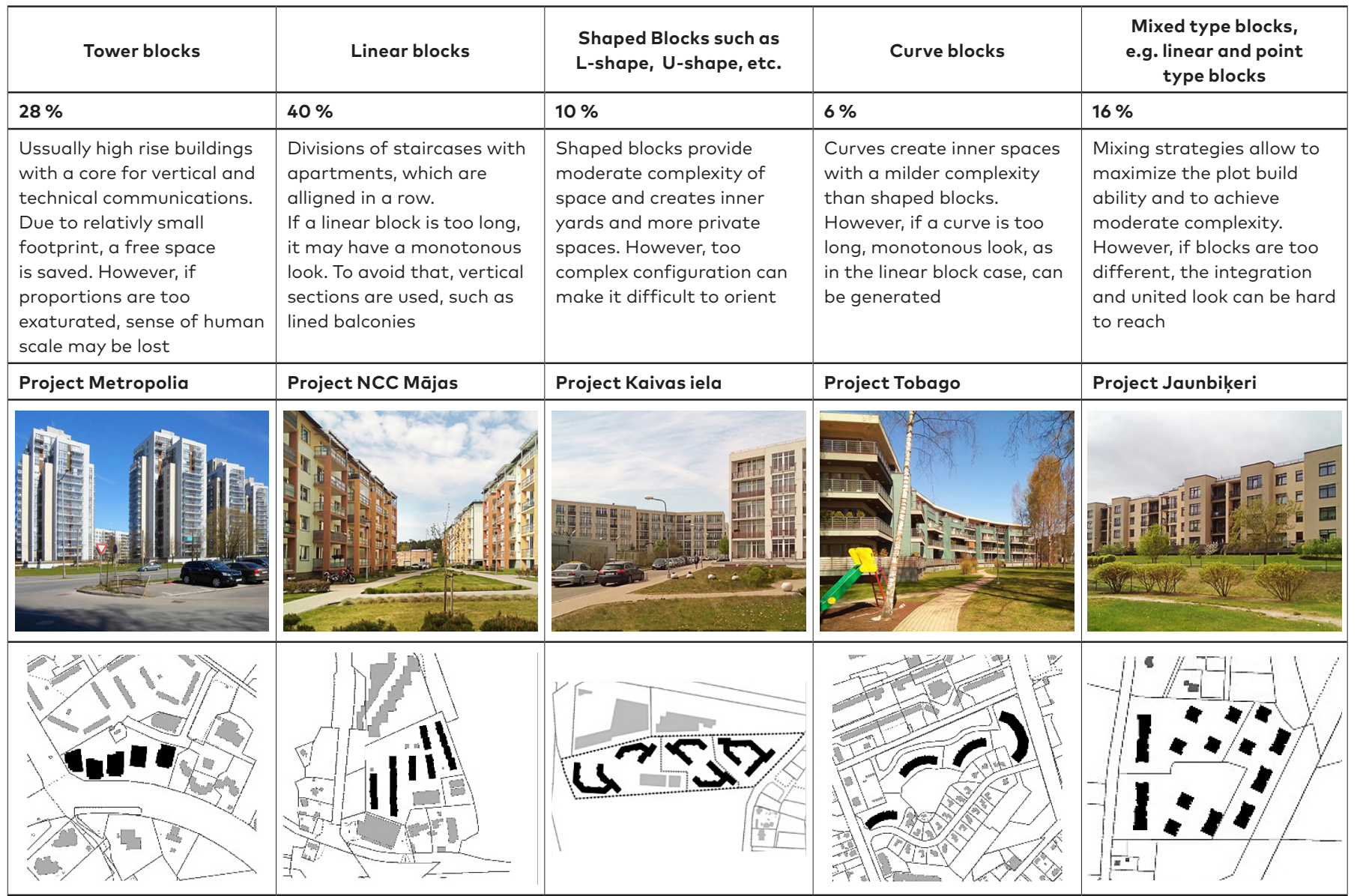

TABLE III

Main Composition Approaches of Riga Contemporary Urban Housing

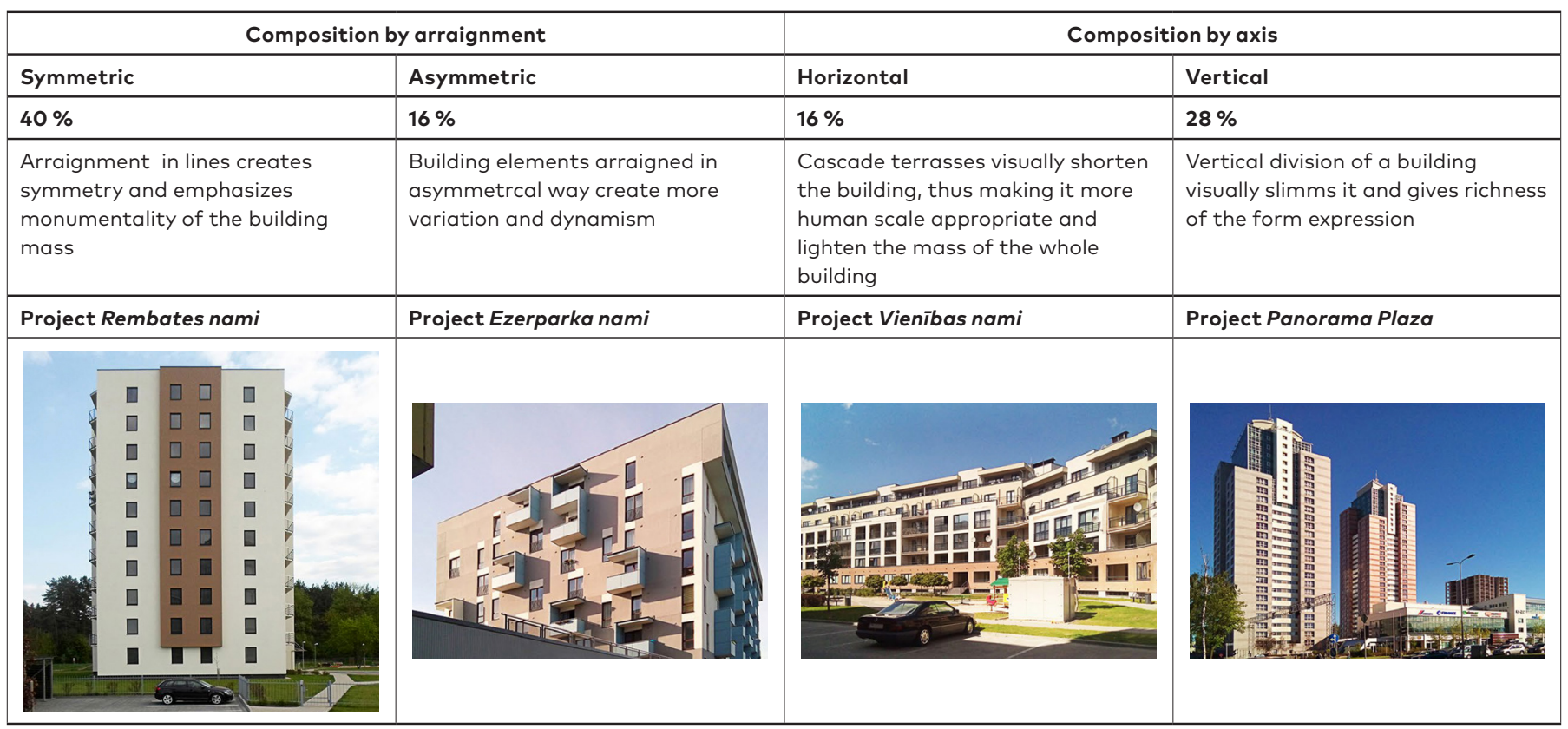




\section{Composition of Facade Elements}

The main building mass includes different elements such as windows, balconies, terraces, etc. These elements not only reflect functional aspects of the building by bringing natural light indoor and providing private outdoor spaces but also plays a significant role in the overall characteristic and aesthetics of the building. Therefore, it is important to pay attention to the element arraignment and compositional approach. The study findings show that mainly symmetry and asymmetry and composition by horizontal or vertical axis are used (Table III). Symmetric approach reflects and integrates well in existing surroundings of historical areas of old

\section{TABLE IV}

\section{Colour Concepts of Contemporary Urban Housing Developments}

\begin{tabular}{|c|c|c|c|c|}
\hline Monochrome & \multicolumn{4}{|c|}{ Polychrome } \\
\hline $18 \%$ & $6 \%$ & $14 \%$ & $45 \%$ & $18 \%$ \\
\hline & Vertical section & Horizontal section & Pop-up accents & Throughout pattern \\
\hline $\begin{array}{l}\text { Works as a background } \\
\text { for different elements } \\
\text { and highlight the building } \\
\text { form, thus creating more } \\
\text { monumental look }\end{array}$ & $\begin{array}{l}\text { Visually divides the building } \\
\text { in smaller segments and } \\
\text { slimms it, thus achieving } \\
\text { a finer and taller look of a } \\
\text { relativly massive block }\end{array}$ & $\begin{array}{l}\text { Visually divides high-rise } \\
\text { buildings and shortens } \\
\text { them to achieve more } \\
\text { appropriate look for human } \\
\text { scale }\end{array}$ & $\begin{array}{l}\text { Brigh colours appear on an } \\
\text { ordinary and calm facade. } \\
\text { Here the colour contrast } \\
\text { and random arraignment } \\
\text { plays a significant role }\end{array}$ & $\begin{array}{l}\text { By usage of one pattern } \\
\text { throughout all facades } \\
\text { a united and visually } \\
\text { saturated look is created }\end{array}$ \\
\hline Project Stopinu iela & Project M Park & Project Filozofu rezidences & Project Ulbrokas iela & Project Imantas 8. Iīnija \\
\hline 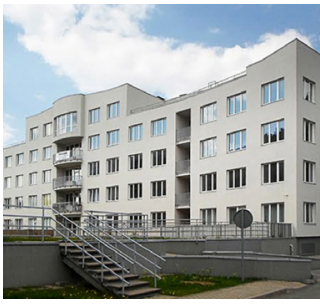 & 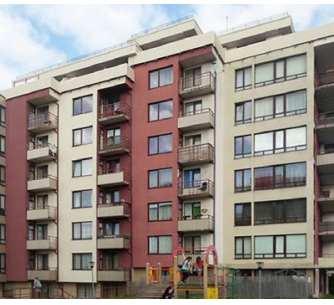 & ( & 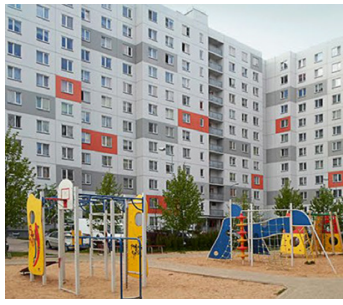 & \\
\hline
\end{tabular}

\section{TABLE V}

Colour Pallet of Riga Contemporary Urban Housing (Photos: Author, Description [30], [31])

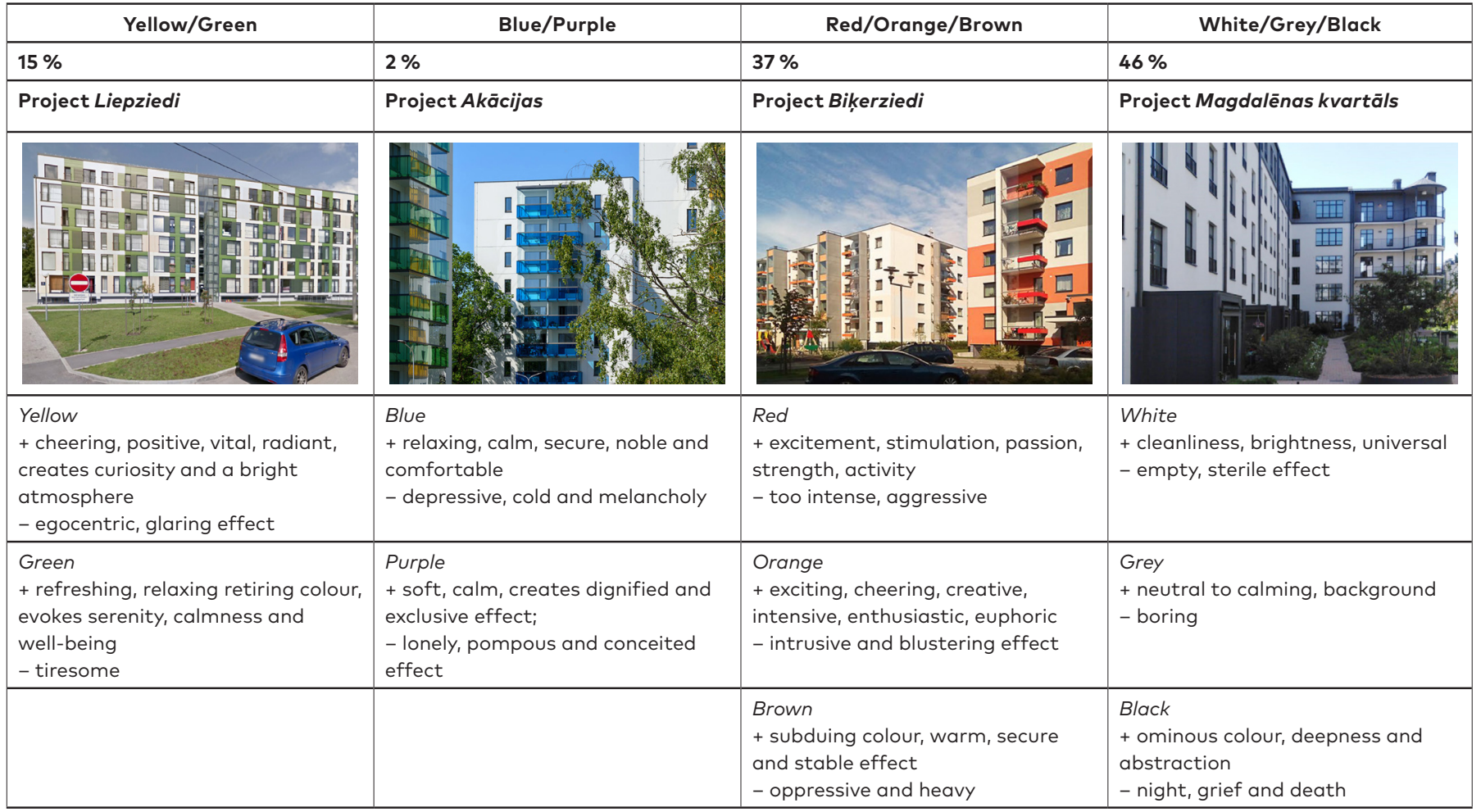


towns as well as in large-scale housing estates of Soviet era. While asymmetric approach, which creates dynamism, is contrasting with surrounding and works more as an accent. Horizontal and vertical section of buildings helps to divide the building's overall form, thus creating building mass appropriate to human scale and integrating it in the surroundings with smaller and/or lower buildings.

\section{Colour Concept}

Facade colour concept also plays an important role in terms of visual identity. Colour approach can create two different outcomes. It can either lead to integration of new construction in existing surroundings or create a contrast of the new and old construction. Results show that monochromatic colour concept is rarely used, whereas polychromatic colour concept is used widely (Table IV). Furthermore, in old town and heritage protective areas, the regulations require integrity, while in new development and periphery areas more contrasting approaches can be observed.

\section{Colour Palette}

Regarding visual identity, not only the overall colour concept but also specific colour plays a significant role. Colour palette as colour approach also may create an integrated or contrasting effect in comparison to the surrounding buildings and nature. Moreover, these colours have also a psychological effect. The study shows that wide variety of grey, yellow and red colours are used (Table V).

\section{Main Results and Discussion}

The main results of visual identity assessment are presented in Table VI.

Throughout centuries the main styles of architecture could be determined by visual attributes such as vertical lines in Gothic and ornamentation of Art Nouveau. The most typical characteristics of Riga 21st century residential developments are linear building blocks, symmetric arraignment of facade elements, polychrome facade colour and usage of white/grey and black colour palette. However, it is not possible to identify one exact visual identity for whole Riga, instead we can observe various trends and approaches. This can be explained by a very rich Riga city urban heritage, which leads to the situation where each part of the city has its own uniqueness and forms diverse obstacles for further development and new construction. Furthermore, new residential developments reflect also current building codes, socio-economic situation as well as architectural practices and other dimensions. In this complexity, it may

\section{TABLE VI}

The Main Visual Identity Assessment Results

\begin{tabular}{|c|c|c|}
\hline Visual identity aspects & Characteristic & Incidence share \\
\hline Building form & $\begin{array}{l}\text { Tower blocks } \\
\text { Linear blocks } \\
\text { Shaped blocks } \\
\text { Curved blocks } \\
\text { Mixed type }\end{array}$ & $\begin{array}{l}28 \% \\
40 \% \\
10 \% \\
6 \% \\
16 \%\end{array}$ \\
\hline \multirow{2}{*}{$\begin{array}{l}\text { Facade element } \\
\text { composition }\end{array}$} & $\begin{array}{l}\text { Symmetric arraignment } \\
\text { Asymmetric } \\
\text { arraignment }\end{array}$ & $\begin{array}{l}40 \% \\
16 \%\end{array}$ \\
\hline & $\begin{array}{l}\text { Horizontal axis } \\
\text { Vertical axis }\end{array}$ & $\begin{array}{l}16 \% \\
28 \%\end{array}$ \\
\hline \multirow[t]{2}{*}{$\begin{array}{l}\text { Facade colour approach } \\
\text { and palette }\end{array}$} & $\begin{array}{l}\text { Monochrome } \\
\text { Polychrome } \\
\text { - vertical section } \\
\text { - horizontal section } \\
\text { - pop-up accents } \\
\text { - throughout pattern }\end{array}$ & $\begin{array}{l}18 \% \\
6 \% \\
6 \% \\
14 \% \% \\
18 \%\end{array}$ \\
\hline & $\begin{array}{l}\text { Yellow/Green } \\
\text { Blue/Purple } \\
\text { Red/Orange/Brown } \\
\text { White/Grey/Black }\end{array}$ & $\begin{array}{l}15 \% \\
2 \% \\
37 \% \\
46 \%\end{array}$ \\
\hline
\end{tabular}

be more appropriate further to focus on architectural grade and Baukultur as mentioned in the Davos Declaration [26], which may also frame the new identity of Latvian architecture.

\section{Conclusions}

Identity of urban environment is a complex concept and has a wide effect on different spheres, including sense of place and human psychology. Due to globalization and urbanization, more and more urgent become issues regarding local context and culture in architecture. Riga has a rich history of architecture which is an important part of new developments. However, identity of 21st century Latvian architecture has not been clarified yet. There are still searches and different discourses, including attempts to identify with Nordic mentality.

Actual physical environment plays a significant role in place identity, sense of place and urban branding. This particular study focuses on three main visual attributes - building form, facade element composition and facade colour. This study provides the first comprehensive assessment of visual identity of Riga contemporary urban housing. The most typical characteristics identified are as follows: linear building blocks, symmetric arraignment of facade elements, polychrome facade colour and usage of white/grey and black colour palette.

In general, this study shows that Riga contemporary urban housing developments have a wide range of visual expressions, thus complementing and enriching urban environment. However, absence of clear Latvian 
architecture identity and usage of formal solutions hinders formation of unique local identity. Further studies could focus on two discourses. Firstly, on resident satisfaction, perception and behaviour, to link the knowledge of physical attributes to actual impact on residents. Secondly, on contextual issues, including architectural grade and Baukultur, especially in terms of regeneration and renovation projects, to achieve integrated approach for further development.

\section{REFERENCES}

1. A_MAG030.Uzbūvētās jaunās dzīvojamās ēkas statistiskajos reǵionos, republikas pilsētās un rajonos (tūkst. $\mathrm{m}^{2}$ kopējās platības), 1990.-2009. g. [online]. Centrālās statistikas pārvalde [cited 02.06.2020.]. https://data.csb.gov.lv:443/ sq/36018

2. A_MAG050. Uzbūvēto dzīvokḷu skaits statistiskajos reǵionos, republikas pilsētās un rajonos, 1997.-2009. g. [online]. Centrālās statistikas pārvalde [cited 02.06.2020.]. https://data.csb.gov.lv:443/sq/35771

3. BUG050. Ekspluatācijā pieñemto jauno dzīvokḷu skaits un platība statistiskajos reǵionos, republikas pilsētās un novados [online]. Centrālās statistikas pārvalde [cited 02.06.2020.]. https://data.csb.gov.lv:443/sq/36016

4. Kadastrs [online, cited 21.05.2020.]. https://www.kadastrs. lv/\#

5. Jaunie mājokḷi [online]. Latio [cited 02.02.2020]. http://latio. lv/lv/jaunie- majokli

6. City24 [online, cited 02.02.2020]. http://www.city24.lv/lv/ jaunie+projekti/latvija?ord=default \&usp $=$ true $\& c=L V \& f r=0$

7. Chapter 6: Lilong Housing as an Urban Form [online]. $M c$ Gill School of Architecture [cited 02.06.2020.]. https://www. mcgill.ca/mchg/student/lilong/chapter6

8. Gieseking, J., Mangold, W., Katz, S., Low, S., Saegert, S. The People, Place, and Space Reader [online, cited 02.06.2020.]. https://peopleplacespace.org/toc/section-3/

9. Ghavampour, E., Vale, B. Revisiting the "Model of Place": A Comparative Study of Placemaking and Sustainability [online]. Cogitatio Press [cited 21.05.2020.]. https:// www.cogitatiopress.com/urbanplanning/article/ download/2015/2015

10. Masterson, V., Stedman, R., Enqvist, J., Tengö, M., Giusti, M., Wahl, D., Svedin, U. The Contribution of Sense of Place to Social-Ecological Systems Research: A Review and Research Agenda [online]. Ecology and Society [cited 21.05.2020.]. https://www.ecologyandsociety.org/vol22/ iss1/art49/\#conclusion17

11. Hu, M., Chen, R. A Framework for Understanding Sense of Place in an Urban Design Context [online]. MDPI [cited 05.01.2021.]. https://www.mdpi.com/2413-8851/2/2/34/ html

12. Rehan, R. M. Urban Branding as an Effective Sustainability Tool in Urban Development. HBRC Journal, 2014, Vol. 10, Issue 2, pp. 222-230.https://doi.org/10.1016/j.hbrcj.2013.11.007

13. Spatial Perception and Architecture [online]. TMD Studio [cited 22.07.2020.]. https://medium.com/studiotmd/ spatial-perception-and-architecture-4f8ab99eeb41
14. Binak Beqaj, B., Rizvanolli, B., Hasimja, G. Creating Urban Sense of Community through Façades Challenge [online]. Research Gate [cited 21.05.2020.]. https:// knowledgecenter.ubt-uni.net/cgi/viewcontent. cgi? article $=2096 \&$ context $=$ conference

15. Importance of Form in Architecture [online]. Plan $n$ Design [cited 07.01.2021.]. https://www.planndesign.com/ articles/2758-importance-form-architecture

16. Understanding the Language and Elements of Design [online]. Whole Building Design Guide [cited 08.01.2021.]. https://www.wbdg.org/design-objectives/aesthetics/ understanding-language-elements-design

17. Roth, L. WEEK 4: Form: Perceptual Laws of Visual Organization (Gestalt Theory) and Compositional Principles (Part 2). [online, cited 08.01.2021.]. https://arch121. cankaya.edu.tr/uploads/files/Week\%204-lecture\%20 notes.pdf

18. Architecture and Experience Series: Color in Architecture [online]. Wortmann-Architect [online, cited 08.01.2021.]. http://www.wortmann-architects.com/color-inarchitecture/\#: :text=Rietveld $\% 20$ used $\% 20$ color $\% 20$ to $\% 20$ separate, on $\% 20$ their $\% 20$ aspect $\% 20$ and $\% 20$ placement

19. Bell, J. A. M. The Role of Colour in Architecture Architecture. Journal of the Society of Dyers and Colourists, 1991, Vol. 107, Issue 7-8, pp. 247-249.

https://doi.org/10.1111/j.1478-4408.1991.tb01345.x

20. The Perception of Color in Architecture [online]. TMD Studio [cited 07.01.2021.]. https://medium.com/studiotmd/theperception-of-color-in-architecture-cf360676776c

21. Krastiṇš, J. Arhitektūras stili Latvijā [online]. Mantojums [cited 21.05.2020.]. https://mantojums.lv/media/uploads/ dokumenti/petijumi/arhitekturas_stili_latvija.pdf

22. Briṇksis, J. Vēsturisko pilsētu telpiskās plānošanas teorija praktiskai kultūras pieminekl̦u aizsardzībai [online]. Research gate [cited 21.05.2020.]. https://mantojums.lv/ media/uploads/dokumenti/petijumi/brinkis_vesturisko_ pilsetu_telpiskas_planosanas_teorija.pdf

23. Rīgas teritorijas plānojums 2006.-2018. Gadam ar grozījumiem galīgā redakcija. Paskaidrojuma raksts [online]. Rìgas domes Pilsētas attīstības departaments [cited 04.08.2019.]. https://www.rdpad.lv/wp-content/ uploads/2014/11/RTP_Paskaidrojuma_raksts_ar_ grozijumiem.pdf

24. Rīgas ilgtspējīgas attīstības stratēgiija līdz 2030. gadam [online]. Rìgas domes Pilsētas attīstības departaments [cited 05.08.2020.]. https://www.rdpad.lv/wp-content/ uploads/2014/11/STRATEGIJA_WEB.pdf

25. Mackenzie, A. Rem Koolhaas: National Identity in Architecture [online]. Architecture $A U$ [cited 21.05.2020.]. https://architectureau.com/articles/national-identity-inarchitecture-an-interview-with-rem-koolhaas/

26. Davos Decleration [online, cited 05.08.2020.]. https://www. newsd.admin.ch/newsd/message/attachments/51119.pdf

27. Priekšlasījums "Ziemel̦u identitāte un Latvijas arhitektūra" [online]. Ziemel̦valstu Ministru padomes birojs Latvijā [cited 04.08.2019.]. https://www.norden.lv/jaunumi/ priekslasijums/ 
28. Krauja, V. Kur meklējama nacionālā identitāte arhitektūrā? Diskusija [online]. Latvijas ziņu portāls [cited 04.08.2019.]. https://www.la.lv/kur-meklejama-nacionala-identitatearhitektura\%E2\%80\%A9-diskusija-2

29. Čivle, A. Radīt vietā un laikā [online]. Arterritory [cited 04.08.2019.]. https://arterritory.com/lv/arhitektura dizains--mode/intervijas/24213-radit_vieta_un_laika

30. Pereira, M. The Role of Color in Architecture: Visual Effects and Psychological Stimuli [online]. Archdaily [cited 19.05.2020.]. https://www.archdaily.com/895498/ the-role-of-color-in-architecture-visual-effects-andpsychological-stimuli

31. The Perception of Color in Architecture [online]. TMD Studio [cited 22.07.2020.]. https://medium.com/studiotmd/theperception-of-color-in-architecture-cf360676776c

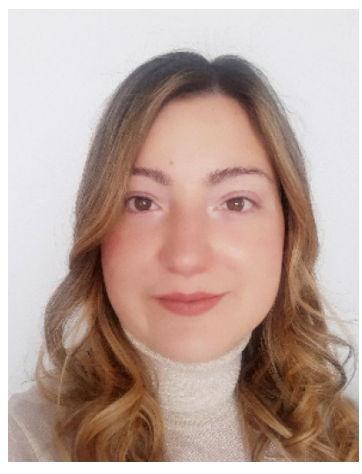

Santa Freimane received a degree of Bachelor of Architecture in 2013, Diploma of Architect in 2015, and Master of Architecture in 2017 from Riga Technical University. Since 2017, she has been a PhD student with the Faculty of Architecture of Riga Technical University. She participated in the Erasmus exchange program at the Polytechnic University of Valencia in 2013. She has been developing her professional skills in several architecture offices in Latvia, Italy, Spain, Germany and Switzerland. Her main research focus is on the quality of contemporary residential environment. She has received the Architect Janis Alksnis Award in 2017.

\section{Contact Data}

Santa Freimane

Faculty of Architecture, Riga Technical University Address: 6 Kīpsalas St., Riga, LV-1048

Phone: +371 25878789

E-mail: arch.santafreimane@gmail.com 